\title{
Studi Komperatif Pemberdayaan Masyarakat Berbasis Partisipasi Melalui Badan Usaha Milik Desa (Panggungharjo, Canden, Dlingo Dan Tirtoharjo) Kabupaten Bantul
}

\begin{abstract}
Evan Stiadi ${ }^{1}$, Muchammad Zaenuri ${ }^{2}$
${ }^{1}$ Program Pascasarjana, Magister Ilmu Pemerintahan, Universitas Muhammadiyah Yogyakarta Jalan Brawijaya, Tamantirto, Kasihan, Bantul Yogyakarta, 55183, Email: evanstiadi@gmail.com ${ }^{2}$ Program Studi Ilmu Pemerintahan, Fakultasi ISIPOL, Universitas Muhammadiyah Yogyakarta Geblagan, Tamantirto, Kec. Bantul, Bantul, Daerah Istimewa Yogyakarta 55183, Email: e_zaenuri@yahoo.com

Abstrak: BUMDes merupakan lembaga untuk memberdayakan masyarakat desa dalam aspek sosial-ekonomi. Di era pembangunan desa, pemerintah berupaya untuk mendorong mendirikan BUMDes sehingga lembaga ini terus banyak bermunculan. Dari BUMDes yang telah berjalan hanya beberapa BUMDes yang mempu memberikan kontribusi untuk pembengunan masyarakat desa yang disalurkan ke Pemerintahan Desa melalui APBDes maupun dirasakan langsung oleh masyarakat. Selajutnya, masih banyak BUMDes-BUMDes yang memiliki persoalan sehingga BUMDes tidak bisa berjalan efektif dalam implementasinya. Oleh karena itu, Tujuan penelitian ini untuk melihat seberapa jauh upaya memberdayakan masyarakat berbasis partisipasi melalui BUMDes. Penelitian ini merupakan penelitian kualitatif dengan pendekatan studi komperatif di Desa Panggungharjo-BUMDes Panggung Lestari, Canden-BUMDes Amrih Makmur, Dlingo-BUMDes Giritama dan Desa Tirtohargo-BUMDes Harum. Hasil penelitian ini menunjukkan ada tiga komponen pemeberdayaan masyarakat berbasis partisipasi melalui BUMDes. pertama, Memberikan Sosialisasi. Kedua, Memeberikan Pelatihan dan pengembangan. Desa panggungharjo dan Desa Dlingo memberikan pelatihan dan pengembangan dalam unit kegiatan BUMDes kepada penelola dan masyarakat desa, sedangkan Desa Canden dan desa tirtohargo kurang maksimal dalam pemberian pelatihan dan pengembangan. ketiga, Partisipasi Masyarakat di antaranya; pertisipasi dalam keputusan, partisipasi dalam pelaksanaan dan partisipasi dalam evaluasi. Penelitian ini menyimpulkan bahwa BUMDes yang mempertimbangkan aspek pemberdayaan masyarakat secara kontiniu akan memberikan efektifitas dalam pengelolaannya, sedangkan BUMDes yang dikelola secara internal Pemerintahan desa dan sedikit melibatkan masyarakat kecenderungannya tidak berjalan efektif.
\end{abstract}

Kata kunci: Pemberdayaan; Partisipasi; BUMDes.

Abstract: BUMDes is an institution for empowering rural communities in the socio-economic aspect. In the era of village development, the government is trying to encourage the establishment of BUMDes so that these institutions continue to emerge. Of the existing BUMDes, only a few BUMDes are able to contribute to the development of village communities which are channeled to the Village Government through APBDes or directly felt by the community. Furthermore, there are still many BUMDes-BUMDes that experience problems so that the BUMDes cannot run effectively in their implementation. Therefore, the purpose of this study is to see the extent to which community empowerment efforts are based on participation through BUMDes. This research is a qualitative study with a comparative study approach in Panggungharjo Village-BUMDes Panggung Lestari, Canden-BUMDes Amrih Makmur, Dlingo-BUMDes Giritama, and Tirtohargo-BUMDes Harum Village. The results of this study indicate that there are three components of participatory-based community empowerment through BUMDes. first, provide socialization. Second, provide training and development. Panggungharjo and Dlingo Villages provide training and development of BUMDes activity units to village and community managers, while Canden and Tirtohargo Villages are less than optimal in providing guidance and development. third, community participation, among others; participation in decisions, participation in implementation, and participation in evaluations. This study concludes that BUMDes that pay attention to aspects of community empowerment continuously will provide effectiveness in their management, while BUMDes that are managed internally by the village government and involve small communities tend to be ineffective.

Keywords: Empowerment; Participation; Village Owned Enterprises

Article History:

Received : 2020-06-14

Revised : 2020-6-26

Accepted : 2020-8-20

\section{PENDAHULUAN}

Badan Usaha Milik Desa (Selanjutnya disingkat BUMDes) sesungguhnya untuk memberikan manfaat bagi masyarakat desa dalam mengembangkan potensi di bidang sosial- 
ekonomi desa. BUMDes merupakan institusi ekonomi di tingkat desa yang diupayakan sebagai sarana peningkatan kesejahteraan masyarakat. BUMDes menjadi bagian penting dari bentuk pemberdayaan ekonomi masyarakat di tingkat desa sejak dimasukkan dalam UU Nomor 6 Tahun 2014. Bahkan, Peraturan Menteri Dalam Negeri Nomor 39 Tahun 2010 meniscayakan kehadiran BUMDes sebagai sentral pengembangan program ekonomi masyarakat dengan mengedepankan prinsip keterbukaan dan bertanggung jawab terhadap masyarakat. Menurut Ridwan (2014) kegiatan ekonomi BUMDes secara ideal dapat menjadi bagian dari usaha peningkatan ekonomi lokal dan regional dalam lingkup perekonomian nasional. Pertumbuhan mendirikan Badan Usaha Milik Desa terus mengalami peningkatan dari tahun ke tahun. Jumlah BUMDes hingga tahun 2017 telah mencapai 22.000 BUMDes dari 74.910 desa, atau meningkat jauh dari tahun 2016 yang berjumlah 18.000 BUMDes dan pada tahun 2014 berjumlah 1.022 (Kompas, 2017a) . Di sisi lain, dari jumlah BUMDes tersebut hanya beberapa yang maju atau sukses, sebagaian besar mengalami masalah dalam pelaksanaanya. Misalnya: BUMDes secara legal formal sudah memiliki institusi tetapi tidak memiliki unik kegiatan usaha secara nyata. Selanjutnya, ada kondisi BUMDes sudah memiliki Unit kegiatan Usaha tetapi banyak mengalami persoalan pengelolaan institusi (Yasa I Kadek Suarita, Purnamawati, \& Sujana, 2017) sehingga BUMDes tidak bisa berjalan secara maksimal, hanya ada "plang papan namanya saja"(Ramadana \& Berlian, 2013).

BUMDes merupakan salah satu serana untuk pemberdayaan masyarakat desa. Menurut Wicaksono, Surya, \& Iskandar (2017) logika pendirian BUMDes didasarkan pada kebutuhan dan potensi desa, sebagai upaya peningkatan kesejahteraan masyarakat. Pilar kegiatan ekonomi melalui BUMDes di desa yang berfungsi sebagai lembaga sosial (social institution) dan komersial (commercial institusion). BUMDes sebagai lembaga sosial berpihak kepada kepentingan masyarakat melalui kontribusinya dalam menyediakan pelayanan sosial (Ridwan, 2014).

Sebagaimana Irawan (2017) menyebutkan upaya pemberdayaan masyarakat desa bagian dari kebijakan afirmatif (affirmative action) atau kebijakan peduli kepada kelompok-kelompok lemah secara politik. Kepedulian ini sudah ada sejak tahun 1998 dalam tindakan afirmatif kepada masyarakt desa diwujudkan dalam bentuk program pemberdayaan, dan salah satunya adalah dalam pemberdayaan kemiskinan (Widjaja, 2012). Kebijakan afirmatif juga mencakup akses terhadap fasilitas pendidikan, kesehatan, dan pekerjaan. Kebijakan untuk meningkatkan partisipasi warga juga dipraktikkan di Brasil, Tiongkok, India, dan Afrika Selatan (DeHaan dan Thorat, 2012). Kebijakan afirmatif diarahkan agar pemanfaat yang pada masa lalu terdiskriminasi kini mampu meningkatkan partisipasinya (Van Jaarsveld, 2000). Oleh sebab itu, kebijakan afirmatif berkaitan dengan nilai keadilan. Terdapat keadilan redistributif di mana pemanfaat kebijakan mendapatkan akses yang sama diambil melalui tindakan mereka Sendiri. Adapun kebijakan korektif merujuk pada tindakan setara untuk mencapai tujuan kesamaan sosial.

Dalam konteks Indonesia, diskriminasi wilayah desa terlihat dalam pembangunan dengan pendekatan top down yang diberlakukan sejak 1970-an. Pola pembangunan desa tersebut berada dalam ranah modernisasi, yang dicirikan oleh upaya menjaga stabilitas politik nasional, subordinasi kota kepada desa, pemasukan teknologi bersama agen-agen dari pemerintah pusat, dan diarahkan untuk meningkatkan produksi pertanian (Tjondronegoro, 1978). Tindakan tradisional atau lokal bukan hanya dinilai ketinggalan zaman, melainkan sampai dianggap menghalangi kemajuan modemisasi.

Meskipun memiliki ciri top down sebagaimana kebijakan yang disusun dari pusat ke daerah dan desa, Undang undang nomor 6 Tahun 2014 tentang Desa bersifat afirmatif terhadap diskriminasi desa pada masa lalu. Undang-undang ini terbit dengan sangat cepat pada akhir tahun pemerintahan Soesilo Bambang Yudhoyono (SBY), dan telah memasuki kampanye pemilihan anggota legislatif serta presiden baru (Antlov. Wetterberg. \& Dharmawan, 2016). 
undang - undang tersebut dimaksudkan untuk melakukan rekognisi wewenang tradisional komunitas desa, memperbaiki tata kelola pemerintahan yang lemah dan memberdayakan masyarakat Desa. Selama proses penyusunan undangundang, perbedaan argumen antarpihak diatasi dengan menyusun hibrida aturan-aturan, yaitu desa mendapatkan rekognisi berupa kesatuan masyarakat hukum. sekaligus rekognisi dari negara untuk pemerintah desa beserta dukungan dan dana. Indikasi UU Nomor 6/2014 sebagai kebijakan afirmatif ditunjukkan dengan mengakui desa adat, mengenalkan mekanisme akuntabilitas pemerintah desa melalui musyawarah desa, peningkatan peran BPD, peningkatan transparansi melalui sistem informasi, kerja sama antardesa, dan dana desa (Antlov. Wetterberg. \& Dharmawan, 2016; Sukasmanto \& Mariana, 2016 ; Vel \& Bedner, 2015).

Terbitnya UU Desa telah menempatkan Desa menjadi wadah kolektif dalam hidup bernegara dan bermasyarakat, hingga tercipta konsep Tradisi Berdesa sebagai konsep hidup bermasyarakat dan bernegara di ranah Desa. Inti gagasan dari Tradisi Berdesa adalah: Pertama, Desa menjadi basis modal sosial yang memupuk tradisi solidaritas, kerjasama, swadaya, dan gotong royong secara inklusif yang melampaui batas-batas eksklusif kekerabatan, suku, agama, aliran atau sejenisnya. Kedua, Desa memiliki kekuasaan dan berpemerintahan yang didalamnya mengandung otoritas dan akuntabilitas untuk mengatur dan mengurus kepentingan masyarakat. Ketiga, Desa hadir sebagai penggerak ekonomi lokal yang mampu menjalankan fungsi proteksi dan distribusi pelayanan dasar kepada masyarakat (Suroto, 2014).

Di lain pihak terdapat Badan Usaha Milik Desa dalam upaya pemberdayaan masyarakat desa. adapun didefinisikan sudah jelas dalam Pasal 1 angka 6 UU No. 6/2014 tentang Desa, sebagai: "Badan Usaha Milik Desa, selanjutya disebut BUM Desa, adalah badan usaha yang seluruh atau sebagian besar modalnya dimiliki oleh Desa melalui penyertaan secara langsung yang berasal dari kekayaan Desa yang dipisahkan guna mengelola aset, jasa pelayanan dan usaha lainnya untuk sebesar-besarnya kesejahteraan masyarakat Desa." Konsepsi Tradisi Berdesa merupakan salah satu gagasan fundamental yang mengiringi pendirian BUMDes. Tradisi Berdesa paralel dengan kekayaan modal sosial dan modal politik serta berpengaruh terhadap daya tahan dan keberlanjutan BUMDes (Putra, 2015). Pola baru yang muncul dalam konteks pemeberdayaan ekonomi masyarakat desa. selajutnya mengundang para peneliti untuk melihat corak perkembangan dan dinamika tata kelola BUMDes. Misalnya dalam penelitian Astuti \& Warsito (2017) menunjukan bahwa proses pembentukan pengawas dapat mempengaruhi kinerja pengawasan karena berpengaruh terhadap kualitas seorang pengawas. Pelaksanaan Pengawasan oleh Badan Pengawas diselenggarakan secara obyektif karena dalam pelaksanaannya Badan Pengawas menggunakan standar yaitu tool administrasi, selain itu pelaksanaan pengawasan dilakukan secara periodik yang tersusun dalam program kerja tahunan Badan Pengawas. Namun terdapat kendala dalam pelaksanaan pengawasan yaitu koodinasi antara Badan Pengawas dengan Manajemen BUMDes terhalang dalam menyesuaikan waktu pertemuan sehingga belum berjalan secara optimal.

Di sisi lain, Fathoni \& Susilowati (2017) menunjukkan bahwa proyek prioritas yang sebaiknya dilaksanakan oleh BUMDes Kemudo Makmur adalah industri palet, wisata sungai, industri pakan dan jasa transportasi. Dalam bobot alternatif, industry palet lebih unggul dalam teknologi, manajemen, sumber daya manusia, keuangan dan sub kriteria hukum, sedangkan perjalanan kaliworo lebih unggul dalam permintaan pasar, persaingan pasar, ketersediaan bahan baku, pemasaran, ekonomi, sosial, dan sub lingkungan. Hasil dari penelitian (Irawati \& Martanti, 2018) menyimpulkan bahwa praktik dari akuntansi yang bersifat transparan dalam bentuk laporan keuangan yang dimiliki oleh BUMDes dan pihak Kantor Desa Karangbendo dalam melaporkan pertambahan aset yang dimiliki oleh instansi dengan panduan "Buku Data Tanah Di Desa Atau Kelurahan Asal Kebupaten”. Kemudian Murwadji, Rahardjo, \& Hasna (2017) membandingkan hambatan efektivitas kedua sarana peningkatan kesejahteraan masyarakat desa, yaitu Koperasi dan BUMDes. Mereka memperlihatkan hambatan permodalan 
yang dialami koperasi tidak perlu diselesaikan dengan pembentukan badan hukum baru, melainkan melalui linkage program antara Bank Umum dengan Koperasi yang dicanangkan Kementerian Koperasi dan Usaha Kecil dan Menengah.

Dalam penlitian Purnamasari \& Disty (2015) Menunjukan pelaksanaan dari kegiatan dilembaga ini tidak bisa lepas peran pemerintah desa yang memberikan dorongan untuk pengurus agar bersikap professional dalam memberikan pelayanan bagi warganya. Dari kegiatan tersebut telah terjadi peningkatan ekonomi bagia warga desa dan juga desa yang terbantu oleh adanya pengelolaan lembaga tersebut, sehingga desa mendapatkan pembagian hasil usaha yang membantu dalam meningkatkan PAD desa. Pelaksanaan peran di BUMDes ini dilaksanakan menjadi dua peran yakni peran fasilitator dan katalisator. Dari pelaksanaa peran ini, banyak warga telah terbantu untuk pengembangan usaha dan lain-lain.

Rahmat \& Ganefanto, (2014) menunjukan menyusun perencanaan BUMDes, dibutuhkan sebuah alat untuk menyusun dan mewujudkan perencaanan tersebut yaitu dengan perencenaan scenario (scenario planning) berdasarkan Tracking, Analysing, Imaging, Deciding, Acting. Pembangunan BUMDes di Desa Karangpatihan yang wujudnya masih belum terlihat, sehingga dibutuhkan juga pembangunan untuk kelembagaan BUMDes tersebut dengan melihat variabelvariabel yaitu kepemimpinan, doktrin, program-program, sumber daya, struktur intern, kaitan memungkinkan, kaitan fungsional, kaitan normatif, kaitan menyebar dan sumber pendapatan desa. Suarita, Purnamawati, \& Sujana (2017) melihat menerapkan restrukturisasi kredit pada BUMDes yaitu penelitian berkas kredit, mengirim surat teguran, melakukan negosiasi, putusan restrukturisasi, dan monitoring. Kebijakan restrukturisasi adalah sistem denda, menambah jatuh tempo atau penjadwalan kembali (rescheduling), dan penyitaan jaminan. Restrukturisasi dengan baik yang ditandai dengan adanya peningkatan SHU setiap tahunnya.

Menteri Desa Pembangunan Daerah Tertinggal dan Transmigrasi Eko Putro Sandjojo memberikan pandangan atas BUMDes yang saat ini sedang berlangsung, menurutnya: "tidak semua BUMDes manajemennya berjalan maksimal. Sebab banyak desa yang belum memiliki sumber daya manusia yang mumpuni untuk mengelola BUMDes. BUMDes ada yang sudah sukses ada yang baru mulai. Yang sukses karena kebetulan memiliki sumber daya manusia yang mampu mengelola BUMDes." (Kompas, 2017b) Sisi lain fungsi dari mendirikan Bumdes adalah untuk memberdayakan mayarakat desa. Pemberdayaan BUMDes merupakan proses pemberdayaan potensi- potensi pembangunan yang ada di desa yang bersumber dari, oleh, dan untuk masyarakat atau dengan kata lain dilaksanakan secara partisipatif (Irawati \& Martanti, 2018).

Keberadaan BUMDes diharapkan dapat mendukung munculnya kembali demokrasi sosial di desa melalui peningkatan kapasitas masyarakat desa tentang pengelolaan BUMDes secara berkelanjutan, dan partisipasi masyarakat desa. Di sisi lain, pemerintah desa juga mampu berpola kreatif dan inovatif dalam mendominasi kegiatan ekonomi desa melalui kepemilikan BUMDes sehingga dapat membangun perekonomian daerah yang dibutuhkan untuk menciptakan lapangan pekerjaan baru, menghasilkan barang dan jasa substitusi daerah, meningkatkan perdagangan antar-pemerintah daerah dan memberikan layanan yang optimal bagi konsumen. Selanjutnya, BUMDes dapat berdiri dengan tujuan sebagai agen pembangunan daerah dan menjadi pendorong terciptanya sektor korporasi di pedesaan tetapi dengan biaya produksi dan pengelolaan tidak terlalu tinggi (Suwondo: 2015).

Senada dengan itu, pelaksanaan BUMDes di Kabupeten Bantul sama kondisi dengan BUMDes di daerah-daerah lain. Ada yang sudah maju dan ada juga yang masih terdapat kendala-kendala di dalam implementasinya. BUMDes dengan katagori sukses di Kabupaten Bantul misalnya BUMDes Lestari milik Desa Panggungharjo dan Bumdes Desamart milik Desa Dlingo. Namun, ada ada juga kondisi BUMDes yang perlu pendampingan seperti BUMDes Harum di Desa Tirtohargo saat ini sudah tidak berjalan sejak tahuan 2013 dan BUMDes Amrih Makmur di Desa Canden yang masih tergendala dalam tata kelola produksi 
unit kegiatan BUMDes-nya (PMD Kab.Bantul 2018). Menjadi pertanyaan selanjutnya, mengapa BUMDes tersebut bisa memiliki aset dan omset serta memiliki efek sosial-ekonomi masyarakat? Sebalik mengapa BUMDes tersebut mengalami banyak persoalan di dalam implentasinya? dan faktor apa yang mempengaruhi? Maka, dipandang perlu untuk melihat kondisi-kondis BUMDes dalam prespektif pembedayaan masyarakat. Karena, Asumsinya bumdes yang bermasalah faktor penyebabnya tidak memiliki nilai pemberdayaan yang bisa diterima oleh masyarakat desa. Oleh karena itu, Melalui konsep pemberdayaan masyarakat akan melihat BUMDes dalam pendekatan penelitian komperatif wilayah di empat desa yaitu Desa Panggungharjo, Canden, Dligo dan Desa Tirtohargo.

\section{METODE PENELITIAN}

Metode pengumpulan data penelitian ini menggunkan pendekatan kualitatif. Menurut (Sugiono, 2013) menyatakan bahwa dalam penelitian kualitatif, pengumpulan data dilakukan dengan natural setting (kondisi yang alamiah), sumber data primer dan teknik pengumpulan data lebih banyak pada observasi berperan serta, wawancara dan dokumentasi. Teknik pengumpulan data merupakan langkah yang paling strategis dalam penelitian data yang digunakan dalam peneliti adalah teknik pengumpulan data yang dilakukan dengan melakukan wawancara dan dokumentasi. Teknik wawancara dilakukan secara langsung dengan informan, selain itu dokumentasi bertujuan agar diperoleh informasi secara baku/tertulis. Hasil dokumentasi akan dicocokkan dengan hasil wawancara sehingga didapatkan data yang akurat dan sesuai dengan kondisi lapangan.

Penelitian ini akan menggunakan data primer yang diperoleh dari wawancara dan obserpasi langsung untuk mengetahui kondisi BUMDes secara mendalam. Untuk menopang argumentasi tesis ini juga menggunakan data-data sekunder baik berupa domuntasi opini dan dibantu dengan data angka-angka bersifat statistik dalam perkembangan BUMDes.

\section{HASIL DAN PEMBAHASAN}

Ada tiga indikator dalam pemberdayaan masyarakat melalui BUMDes; Pertama, BUMDes memberikan Sosialiasi kepada masyarakat desa; Kedua, Meberikan Pelatihan dan Pengembangan kepada Pengelola BUMDes sekaligus kepada masyarakat desa; ketiga, melibatkan partisipasi masyarakat disetiap tahap-tahapan pelakasaan kegiatan BUMDes. ketiga indicator ini merupakan bagian dari output yang dihasilkan BUMDes dalam pendekatan Pemberdayaan masyarakat berbasis partisiapasi di antaranya, terciptanya kondisi BUMDes yang memiliki suasana partisipasi masyarakat yang terus meningkat, BUMDes menjadi pilar pendorong berkembangnya usaha masyarakat dan BUMDes mampu memanfaatkan potensi desa untuk dijadikan sumber ekonomi masyarakat. Selanjutnya, penghasilan BUMDes juga bisa membantu pembangunan desa yang disalurkan di dalam PADes setiap tahunnya.

\section{Pemberian Sosialisasi BUMDes Panggung Lestari, Amrih Makmur, Giritama dan Harum}

Sosialisasi merupakan proses menyesuaikan diri terhadap norma-norma sosial yang berlaku, dengan tujuan supaya orang yang bersangkutan dapat diterima menjadi anggota suatu masyarakat. Dalam konteks sosialisasi suatu program, proses sosialisasi bertujuan untuk menyebarluaskan informasi tertentu kepada khalayak agar bisa dimengerti dan diterima dalam suatu lingkungan masyarakat. Secara umum, proses sosialisasi membutuhkan partisipasi aktif dari masyarakat. Penelitian ini, sosialisasi ditempatkan sebagai salah satu indikator untuk mengukur proses pemberdayaan partisipatif masyarakat dalam pengelolaan BUMDes. Pengelolaan BUMDes yang mengedepankan proses pemberdayaan masyarakat tentu memiliki proses sosialisasi yang melibatkan masyarakat secara partisipatif. Sosialisasi menjadi penting 
bagi BUMDes sebab merupakan langkah awal dalam menggerakkan BUMDes agar bisa berkembang dengan baik.

Tabel 1. Pemetaan Komperatif Sosialisasi BUMDes Panggung Lestari, Amrih Makmur, Giritama dan Harum

\begin{tabular}{lllll}
\hline & $\begin{array}{l}\text { BUMDes Panggung } \\
\text { Lestari }\end{array}$ & BUMDes Amrih Makmur & BUMDes Giritama & BUMDes Harum \\
\hline $\begin{array}{l}\text { Sosiasasi } \\
\text { Penentuan Unit } \\
\text { Usaha BUMDes }\end{array}$ & $\begin{array}{l}\text { Menetapkan kegiatan } \\
\text { KUPAS bagian dari } \\
\text { Unit Usaha BUMDes }\end{array}$ & $\begin{array}{l}\text { Menetapkan produksi Air } \\
\text { Minum "RO” sebagai Unit } \\
\text { Usaha BUMDes pengganti } \\
\text { usaha "Photo Copy" }\end{array}$ & $\begin{array}{l}\text { Menetapkan Desamart } \\
\text { sebagai Unit Usaha } \\
\text { BUMDes }\end{array}$ & $\begin{array}{l}\text { Menetapkan Program } \\
\text { Simpan-pijam sebagai } \\
\text { Unit Usaha BUMDes }\end{array}$ \\
\hline $\begin{array}{llll}\text { Sosialiasi } \\
\text { kegiatan }\end{array}$ & Sosialiasi kegiatan & Sosialisasi penjualan Air & Sosialiasi kegiatan & Sosialasi kegiatan \\
BUMDes & BUMDes system & Minum "RO" & Desamart & Simpan-pinjam \\
\hline $\begin{array}{l}\text { Media } \\
\text { sosialisasi }\end{array}$ & Forum formal rapat desa & Forum formal rapat desa & Forum formal rapat desa & Forum formal rapat \\
& Poster & & Facebook & desa \\
\hline $\begin{array}{l}\text { Sasaran } \\
\text { Sosialisasi }\end{array}$ & Web desa & & Pemerintahan Desa, BPD, & Pemerintahan Desa, \\
& BPD, Paguyuban dan & Masyarakat Desa & Paguyuban dan \\
Masyarakat Desa & & Masyarakat Desa & Desa \\
\hline
\end{tabular}

Secara umum proses sosialisasi yang dilakukan oleh empat BUMDes tersebut terlaksana dan sudah dilakukan. Namun dalam prosesnya dapat dilihat tingkat kreativitas dan daya tarik dari setiap proses sosialisasi yang dilakukan oleh BUMDes. Ada BUMDes yang secara maksimal melakukan sosialisasi, ada juga yang hanya melakukan sekedarnya saja. BUMDes yang maksimal dalam proses sosialisasi tentu mampu melibatkan berbagai aspek yang bisa mendukung proses sosialisasi tersebut, salah satunya adalah perkembangan teknologi dan informasi. BUMDes Panggung Lestari dan BUMDes Giritama dalam hal ini tampak berhasil memanfaatkan aspek ini sebagai media sosialisasi dan berdampak pada partisipasi masyarakat yang lebih banyak dalam mengikuti proses sosialisasinya. Sebaliknya BUMDes Amrih Makmur dan BUMDes Harum, yang hanya mengandalkan forum-forum desa ternyata tampak kurang maksimal dalam proses sosialisasinya. Hal ini tampak pada program yang dijalankan oleh BUMDes ini berjalan kurang lancar sebagaimana yang telah dijelaskan

Proses sosialisasi ini penting dalam hal pemberdayaan masyarakat, sebab sosialisasi pada dasarnya adalah pintu utama dari aktivitas partisipasi. Pemberdayaan masyarakat yang baik harus didukung oleh partisipasi masyarakat yang baik. Jadi sosialisasi yang baik akan menghasilkan pemberdayaan masyarakat yang baik. Sebaliknya sosialisasi yang kurang baik akan menghasilkan permberdayaan masyarakat yang kurang baik juga. Sebagaimana studi yang dilakukan oleh Rizal Andreeyan (2014) menjelaskan bahwa proses sosialisasi yang kurang maksimal berakibat pada terhambatnya kegiatan pemberdayaan masyarakat.

\section{Pemberian Pelatihan Pelatihan dan Pengembangan BUMDes Panggung Lestari, Amrih Makmur, Giritama dan Harum}

Pemberdayaan masyarakat sejatinya bertujuan untuk membentuk individu dan masyarakat menjadi mandiri. Kemandirian tersebut meliputi kemandirian berpikir, bertindak dan mengendalikan apa yang mereka lakukan tersebut. Dalam upaya mewujudkan kemandirian masyarakat tentu harus dilakukan dengan media pelatihan dan pengembangan. Pelatihan dan pengembangan menjadi sarana pendidikan untuk mewujudkan masyarakat yang berdaya.

Studi dari Widjajanti (2011) membuktikan bahwa modal manusia berperan memainkan perubahan sumber daya masyarakat untuk meraih kesuksesan proses pemberdayaan. Modal manusia ditandai adanya tingkat pendidikan yang memadai yang diperoleh dari dukungan pengembangan sarana dan prasarana pendidikan sehingga dapat mengembangkan pemberdayaannya dan akan berdampak secara signifikan pada kemandirian masyarakat. Dari studi ini dapat dilihat bagaimana proses pendidikan masyarakat menjadi poin penting dalam mewujudkan pemberdayaan masyarakat. Sebab dalam proses pemberdayaan, masyarakat 
merupakan objek utama yang harus diberi pendidikan. Masyarakat yang memiliki kemampuan setelah diberi pendidikan akan mampu berdaya dan mandiri.

Tabel 2. Pemetaan Komperatif Pelatihan dan Pengembangan BUMDes Panggung Lestari, Amrih Makmur, Giritama dan Harum

\begin{tabular}{|c|c|c|c|c|}
\hline & $\begin{array}{l}\text { Bentuk Pelatihan dan } \\
\text { pengembangan }\end{array}$ & Sifat & $\begin{array}{l}\text { Sasaran Pelatihan dan } \\
\text { pengembangan }\end{array}$ & $\begin{array}{l}\text { Pelaksana Kegiatan } \\
\text { Pelatihan dan } \\
\text { Pengembangan }\end{array}$ \\
\hline $\begin{array}{l}\text { BUMDes Panggung } \\
\text { Lestari }\end{array}$ & $\begin{array}{l}\text { Pelatihan Adm BUMDes } \\
\text { Pelatihan Produksi Unit Usaha } \\
\text { Pelatihan pengembangan } \\
\text { BUMDes }\end{array}$ & Formal & $\begin{array}{l}\text { Pengurus BUMDes } \\
\text { Karyawan } \\
\text { Masyarakat }\end{array}$ & $\begin{array}{l}\text { BUMDes Panggung Lestari } \\
\text { PEMDA Bantul } \\
\text { Kerja sama Lembaga }\end{array}$ \\
\hline $\begin{array}{l}\text { BUMDes Amrih } \\
\text { Makmur }\end{array}$ & $\begin{array}{l}\text { Pelatihan Pengembangan } \\
\text { BUMDes } \\
\text { Pendampingan informal Teknis } \\
\text { Produksi Unit usaha }\end{array}$ & $\begin{array}{l}\text { Formal } \\
\text { Informal }\end{array}$ & $\begin{array}{l}\text { Pengurus BUMDes } \\
\text { Operator Produksi Unit } \\
\text { Usaha }\end{array}$ & $\begin{array}{l}\text { PEMDA Bantul } \\
\text { BUMDes Amrih Makmur }\end{array}$ \\
\hline BUMDes Giritama & $\begin{array}{l}\text { Pelatihan Adm BUMDes } \\
\text { Pelatihan Produksi Unit Usaha } \\
\text { Pelatihan pengembangan } \\
\text { BUMDes }\end{array}$ & Formal & $\begin{array}{l}\text { Pengurus BUMDes } \\
\text { Karyawan } \\
\text { Masyarakat }\end{array}$ & $\begin{array}{l}\text { BUMDes Giritama } \\
\text { PEMDA Bantul } \\
\text { Kerja sama Lembaga }\end{array}$ \\
\hline BUMDes Harum & $\begin{array}{l}\text { Pelatihan pengembangan } \\
\text { BUMDes }\end{array}$ & Formal & Pengurus BUMDes & PEMDA Bantul \\
\hline
\end{tabular}

Untuk melihat proses pemberdayaan masyarakat dalam pengelolaan BUMDes di empat desa yang diteliti dalam penelitian ini, maka perlu ditinjau proses pelatihan dan pengembangan yang melibatkan masyarakat berlangsung. Sejauh mana BUMDes mampu menjadi media pendidikan masyarakat di empat desa tersebut. Berikut ini akan dipaparkan proses pelatihan dan pengembangan masyarakat yang dilakukan oleh BUMDes di empat desa ini. Dari gambaran empat BUMDes ini, teridentifikasi bahwa ada dua BUMDes yang proses pemberdayaan masyarakat melalui program pelatihan dan pengembangan berjalan maksimal dan ada dua BUMDes yang berjalan kurang maksimal. BUMDes yang program pelatihan dan pengembangannya maksimal adalah BUMDes Panggung Lestari dan BUMDes Giritama. Sedangkan BUMDes yang kurang maksimal adalah BUMDes Amrih Makmur dan BUMDes Harum.

Meskipun demikian, pada dasarnya keempat BUMDes ini sudah berupaya untuk melakukan pemberdayaan masyarakat dari program pelatihan dan pengembangan. Dimana dari program pelatihan dan pengembangan ini dapat meningkatkan kemampuan masyarakat. Berbagai ilmu pengetahuan baru dapat diserap oleh masyarakat. Semakin banyak pelatihan dan pengembangan yang dilakukan oleh BUMDes, maka semakin banyak pula ilmu dan kemampuan yang diterima oleh masyarakat. Dalam hal ini dapat dikatakan proses pemberdayaan masyarakat berjalan baik. Begitu juga sebaliknya, semakin sedikiti pelatihan dan pengembangan yang dilakukan BUMDes, maka ilmu dan kemampuan masyarakat juga sedikit. Proses pemberdayaan masyarakat dapat dikatakan berjalan kurang baik.

\section{Pemetaan Partisipasi Masyarakat dalam BUMDes Panggung Lestari, Amrih Makmur, Giritama dan Harum}

Partisipasi masyarakat dalam setiap agenda kegiatan desa merupakan tanggung jawab masyarakat desa. Masyarakat yang peduli dengan desa tentu akan senantiasa terlibat dalam kegiatan-kegiatan yang bertujuan untuk memajukan desa. Proses keterlibatan masyarakat dalam setiap agenda kegiatan desa inilah yang disebut dengan partisipasi masyarakat. Menurut Sambodo (2006) partisipasi merupakan suatu proses yang memungkinkan adanya interaksi yang lebih baik antar stakeholders sehingga kesepakatan-kesepakatan dan tindakan yang bersifat inovatif lebih mungkin tercipta dalam proses deliberatif, dimana ruang untuk mendengarkan, belajar, refleksi dan memulai suatu aksi bersama terjadi.

Dalam konteks pembangunan Adisasmita (2006) mengatakan partisipasi masyarakat adalah keterlibatan dan pelibatan anggota masyarakat dalam pembangunan, meliputi kegiatan 
dalam perencanaan dan pelaksanaan (implementasi) program/proyek pembangunan yang dikerjakan di masyarakat lokal. Partisipasi atau peran serta masyarakat dalam pembangunan merupakan aktualisasi dari ketersediaan dan kemauan anggota masyarakat untuk berkorban dan berkontribusi dalam implementasi program/ proyek. Ia juga mengatakan bahwa partisipasi masyarakat adalah pemberdayaan masyarakat, peran sertanya dalam kegiatan penyusunan perencanaan dan implementasi program/ proyek pembangunan, dan merupakan aktualisasi kesedia dan kemauan masyarakat untuk berkorban dan berkontribusi terhadap implementasi pembangunan.

Dalam konteks pemberdayaan masyarakat, partisipasi masyarakat menjadi penting untuk dibicarakan. Partisipasi masyarakat adalah ujung tombak dalam proses pemberdayaan masyarakat. Prinsip partisipasi menuntut masyarakat harus diberdayakan, diberikan kesempatan dan diikutsertakan untuk berperan dalam proses-proses birokrasi mulai dari tahap perencanaan pelaksanaan dan pengawasan atau kebijakan publik. Partisipasi masyarakat merupakan kontrol adanya kekuasaan yang berlebih agar lebih efektif ditujukan sebesarbesarnya untuk masyarakat dalam konsep good governance. Adanya ruang keterlibatan warga dan kerangka kelembagaan yang sesuai dalam partisipasi turut mendorong pembangunan dan pemerataan.

Proses pemberdayaan masyarakat yang baik tentu akan diiringi oleh derajat partisipasi masyarakat yang tinggi juga. Bukti bahwa suatu masyarakat berdaya adalah adanya aktivitas yang dilakukan oleh masyarakat sehingga tujuan yang diinginkan bisa tercapai. Dalam hal pengelolaan BUMDes, proses pemberdayaan masyarakat akan dapat tergambarkan dengan jelas dari partisipasi masyarakat dalam agenda-agenda BUMDes tersebut. Pada prinsipnya BUMDes diharapkan mampu menstimulasi dan menggerakkan roda perekonomian di pedesaan. Aset ekonomi yang ada di desa harus dikelola sepenuhnya oleh masyarakat desa. Substansi dan filosofi BUMDes harus dijiwai dengan semangat kebersamaan dan selfhelp sebagai upaya memperkuat aspek ekonomi kelembagaannya.

Partisipasi masyarakat dalam proses pengelolaan BUMDes di empat desa yang diteliti dalam penelitian ini akan dijelaskan melalui pendekatan konsep dari Cohen dan Uphoff. Dimana Cohen dan Uphoff dalam Ndraha (1990) menguraikan bentuk-bentuk partisipasi yang terbagi dalam empat bentuk, yaitu : partisipasi dalam pembuatan keputusan (participation in decision making), partisipasi dalam pelaksanaan (participation in implementation), partisipasi dalam menerima manfaat (participation in benefits), partisipasi dalam evaluasi (participation in evaluation).

Tabel 3. Pemetaan Partisipasi Masyarakat dalam BUMDes Panggung Lestari, Amrih Makmur, Giritama dan Harum

\begin{tabular}{|c|c|c|c|c|}
\hline $\begin{array}{l}\text { Pertisipasi } \\
\text { Masyarakat }\end{array}$ & $\begin{array}{l}\text { BUMDes Panggung } \\
\text { Lestari }\end{array}$ & $\begin{array}{l}\text { BUMDes Amrih } \\
\text { Makmur }\end{array}$ & BUMDes Giritama & BUMDes Harum \\
\hline $\begin{array}{l}\text { Partisipasi } \\
\text { Membuat } \\
\text { Keputusan }\end{array}$ & $\begin{array}{l}\text { Perumusahan BUMDes di } \\
\text { Musyawarah Desa } \\
\text { Pendekatan Perwakilan } \\
\text { Masyarakat }\end{array}$ & $\begin{array}{l}\text { Perumusahan BUMDes } \\
\text { di Musyawarah Desa di } \\
\text { lingkungan PEMDes }\end{array}$ & $\begin{array}{l}\text { Perumusahan BUMDes di } \\
\text { Musyawarah Desa }\end{array}$ & $\begin{array}{l}\text { Perumusahan } \\
\text { BUMDes di } \\
\text { Musyawarah Desa }\end{array}$ \\
\hline $\begin{array}{l}\text { Partisipasi } \\
\text { Pelaksanaan }\end{array}$ & $\begin{array}{l}\text { Pengelola BUMDes } \\
\text { Karyawan } \\
\text { Pelanggan }\end{array}$ & $\begin{array}{l}\text { Pengelola BUMDes } \\
\text { Pelanggan }\end{array}$ & $\begin{array}{l}\text { Pengelola BUMDes } \\
\text { Pelanggan/penjual barang } \\
\text { dan saja }\end{array}$ & $\begin{array}{l}\text { Pengelola BUMDes } \\
\text { nasabah }\end{array}$ \\
\hline $\begin{array}{l}\text { Partisipasi } \\
\text { evaluasi }\end{array}$ & $\begin{array}{l}\text { Forum Evaluasi BUMDes } \\
\text { Tahunan Pendekatan } \\
\text { Perwakilan Masyarakat }\end{array}$ & $\begin{array}{l}\text { Forum Evaluasi dihadiri } \\
\text { oleh Pengurus BUMDes } \\
\text { dan PEMDes }\end{array}$ & $\begin{array}{l}\text { Forum Evaluasi BUMDes } \\
\text { Tahunan Pendekatan } \\
\text { Perwakilan Masyarakat }\end{array}$ & $\begin{array}{l}\text { Forum Evaluasi } \\
\text { dihadiri oleh Pengurus } \\
\text { BUMDes dan } \\
\text { PEMDes }\end{array}$ \\
\hline $\begin{array}{l}\text { Gambaran Umum } \\
\text { Partisipasi } \\
\text { Masyarakat }\end{array}$ & $\begin{array}{l}\text { Melibatkan Masyarakat } \\
\text { Dalam Keputusan Umum } \\
\text { BUMDes } \\
\text { Masyarakat sebagai } \\
\text { Pengelola, Pelanggan dan } \\
\text { Karyawan }\end{array}$ & $\begin{array}{l}\text { Masyarakat sebagai } \\
\text { Pelanggan }\end{array}$ & $\begin{array}{l}\text { Masyarakat sebagai } \\
\text { Pelanggan dan penjual } \\
\text { barang/jasa } \\
\text { Melibatkan Masyarakat } \\
\text { Dalam Keputusan Umum } \\
\text { BUMDes }\end{array}$ & $\begin{array}{l}\text { Masyarakat sebagai } \\
\text { Nasabah }\end{array}$ \\
\hline
\end{tabular}


Secara umum keempat BUMDes ini telah membuka ruang partisipasi masyarakat dalam proses pengelolaan BUMDes. Ruang partisipasi terbuka dari setiap proses dan berjalannya program dari unit usaha BUMDes. Meskipun demikian derajat tingkat partisipasi masyarakat disetiap BUMDes dapat diidentifikasi berjalan dengan beragam. Ada BUMDes yang tingkat partisipasinya tinggi dan ada pula BUMDes yang tingkat partisipasinya rendah.

BUMDes yang tingkat partisipasinya tinggi pada prakteknya disebabkan karena ruang partisipasi yang banyak dari ruang pengelolaan lembaga dan unit usaha yang ada. Unit usaha yang banyak dan berjalan lancar mengakibatkan tingkat partisipasi masyarakat berjalan baik. Sedangkan BUMDes yang unit usahanya sedikit dan tidak berjalan lancar membuat tingkat partisipasi masyarakat menjadi rendah. Dari gambaran diatas dapat dilihat bahwa BUMDes Panggung Lestari dan BUMDes Giritama tingkat partisipasinya cukup tinggi, sedangkan BUMDes Amrih Makmur dan BUMDes Harum tingkat partisipasinya kurang optimal.

\section{KESIMPULAN DAN SARAN}

Mengacu pada analisis data yang telah diuraikan pada bab-bab sebelumnya, maka penelitian ini secara umum akan menyimpulkan beberapa argumen yang berupaya untuk menjawab pertanyaan penelitian. Argumen tersebut yaitu pemberdayaan masyarakat pada prinsipnya merupakan penciptaan suasana atau iklim yang memungkinkan potensi masyarakat berkembang (enabling). Logika ini didasarkan pada asumsi bahwa tidak ada masyarakat yang sama sekali tanpa memiliki daya. Setiap masyarakat pasti memiliki daya, akan tetapi kadangkadang mereka tidak menyadari atau daya tersebut masih belum diketahui secara eksplisit. Oleh karena itu daya harus digali dan kemudian dikembangkan. Asumsinya BUMDes yang mampu beroperasi dengan baik tentu telah didukung oleh partisipasi masyarakat yang baik juga. Kondisi ini kemudian menunjukkan bagaimana proses pemberdayaan masyarakat berhasil berjalan dengan baik.

Pemberdayaan masyarakat yang berlangsung dalam keempat BUMDes yang diteliti secara umum berjalan baik. Meskipun jika dikaji lebih dalam dengan indikator sosialiasi, pelatihan dan partisipasi masyarakat terdapat perbedaan kualitasi pemberdayaan. Penelitian ini menunjukkan bahwa BUMDes Panggung Lestari dan BUMDes Giritama memiliki kualitas pemberdayaan masyarakat yang lebih baik dari BUMDes Amrih Makmur dan BUMDes Harum. BUMDes Panggung Lestari memiliki proses sosialisasi yang baik, proses pelatihan dan pengembangan yang baik dan didukung oleh partisipasi masyarakat yang baik juga. Kemudian BUMDes Giritama juga memiliki proses sosialisasi yang baik, proses pelatihan dan pengembangan yang baik dan partisipasi masyarakat yang baik. Sedangkan BUMDes Amrih Makmur proses sosialisasinya baik, proses pelatihan dan pengembangan kurang optimal dan partisipasi masyarakat kurang optimal. Begitu juga dengan BUMDes Harum proses sosialisasinya baik namun untuk proses pelatihan dan partisipasi masyarakatnya kurang optimal. Sedangkan BUMDes yang proses pengelolaan lembaga dan unit usaha biasa saja bahkan sampai bermasalah akan berdampak pada proses pemberdayaan masyarakat yang kurang optimal.

Penelitian yang menggali aktivitas pemberdayaan masyarakat sebagaimana yang dilakukan dalam penelitian ini sejatinya harus terus ditingkatkan. Terutama penelitian yang fokus pada objek BUMDes. BUMDes sebagai sarana yang pemberdayaan ekonomi desa diharapkan harus dikelola dengan baik. Adanya peraturan perundang-undangan baru terkait desa telah membuka ruang bagi BUMDes agar bisa berkontribusi bagi desa. Oleh karena itu kajian-kajian terkait BUMDes harus selalu dikaji dan dievaluasi, terutama bagaimana inovasiinovasi yang diterapkan dalam pengelolaannya.

Selanjutnya pada bagian akhir ini, sebagai bahan refleksi untuk penelitian ini, maka akan dipaparkan beberapa saran dan rekomendasi yang diharapkan berguna kedepannya. 
Pertama, bagi Pemerintah sebagai institusi induk yang menaungi keberadan BUMDes. Penelitian ini diharapkan mampu menjadi bahan evaluasi bagi pihak pemerintah terutama bagi Pemerintah Desa Panggungharjo, Canden, Dlingo dan Tirtohargo. Evaluasi yang dimaksud adalah terkait dengan operasional BUMDes yang berdampak pada proses pemberdayaan masyarakat. Dimana Pemerintah Desa bisa mengevaluasi program dan proses pengelolaan lembaga yang baik dari setiap BUMDes. Hal ini penting dilakukan untuk kelangsungan BUMDes agar tetap bisa menjadi media pemberdayaan masyarakat.

\section{DAFTAR PUSTAKA}

Adisasmita, R. (2006). Pembangunan Pedesaan dan Perkotaan. Yogyakarta: Graha Ilmu.

Antlov. Wetterberg. \& Dharmawan. (2016). Village Governance, Community Life, and the 2014 Village Law in Indonesia. Bulletin of Indonesiaan Economic Studies, Vol. 52 No.

Astuti, P. F., \& Warsito. (2017). Pelaksanaan Fungsi Pengawasan BUMDes Desa Ponggok Kecamatan Polanharjo Kabupaten Klaten. Journal of Politic and Government Studies, 6(2), 291-300. Retrieved from https://ejournal3.undip.ac.id/index.php/jpgs/article/view/16127

DeHaan dan Thorat. (2012). Addressing Group Inequalities : Social Policies in Emerging Economies' Geat Transformation. European Journal of Development Research, No.24.

Fathoni, S., \& Susilowati, I. (2017). Penentuan Prioritas Proyek Menggunakan Fuzzy Analytic Network Prosess (Studi Kasus BUMDes Desa Kemudo Kecamatan Prambanan Kabupaten Klaten).

Irawan, N. (2017). Tata Kelola Pemerintahan Desa Era UU Desa. Jakarta: Yayasan Pustaka Obor Indonesia.

Irawati, D., \& Martanti, D. E. (2018). Transparasi Pengelolaan Laporan Keuangan BUMDes terhadap Pelaporan Aset Desa (Studi Fenomenologi Pada BUMDes Desa Karangbendo Kec Ponggok Kab Blitar). UNEJ E-Proceeding, 41-51.

Kompas. (2017a). Jumlah Badan Usaha di Desa Meningkat. Retrieved November 7, 2017, from https://www.pressreader.com/indonesia/kompas/20170517/281981787517430

Kompas. (2017b). Jumlah BUMdes Mencapai 18.446. Retrieved November 7, 2017, from http://ekonomi.kompas.com/read/2017/03/27/185143526/jumlah.bumdes.mencapai.18.44 6.unit

Murwadji, T., Rahardjo, D. S., \& Hasna. (2017). Koperasi Versus BUMDes dalam Peningkatan Kesejahteraan Masyarakat Desa. ACTA DIURNAL Jurnal Ilmu Hukum Kenotariatan, 1(1).

Ndraha, T. (1990). Pembangunan Masyarakat. Jakarta: Rinika Cipta.

Purnamasari, \& Disty. (2015). Peran Badan Usaha Milik Desa (BUMDes) dalam Meningkatkan Kesejahteraan Masyarakat Desa (Studi Kasus Desa Minggirsari, Kecamatan Kanigoro, Kabupaten Blitar). Jurnal Administrasi Publik, 3(10), 1655-1660.

Putra, A. S. (2015). Badan Usaha Milik Desa: Spirit Usaha Kolektif Desa. Jakarta: KDPDTT.

Rahmat, \& Ganefanto, A. B. (2014). Perancanaan Skenario Badan Usaha Milik Desa (BUMDes) untuk Menambah Sumber Pendapatan Desa (Studi di Desa Karangpatihan, Kecamatan Balong, Kabupaten Ponorogo). Jurnal Administrasi Publik, 2(8).

Ramadana, \& Berlian, C. (2013). Keberadaan Badan Usaha Milik Desa (BUMDES) sebagai Penguatan Ekonomi Desa. Jurnal Administrasi Publik, 1(6), 1068-1076.

Ridwan, Z. (2014). Urgensi Badan Usaha Milik Desa (BUMDes) dalam Pembangun 
Rizal Andreeyan. (2014). Studi Tentang Partisipasi Masyarakat dalam Pelaksanaan Pembangunan di Kelurahan Sambutan Kecamatan Sambutan Kota Samarinda. Jurnal Administrasi Negara UNMUL, 2. No.4.20.

Sambodo, H. (2006). Partisipasi Masyarakar dalam Pembangunan Desa (Malang). Unibraw.

Sugiono. (2013). Metode Penelitian Pendidikan Pendekatan Kuantitatif, Kualitatif dan R\&D. Bandung: Alfabeta.

Sukasmanto \& Mariana. (2016). Modul Panduan Menyusun Kewenangan dan Perancanaan Desa. Institute for Reseacrh and Empowerment. Yogyakarta.

Suroto, E. (2014). Desa Membangun Indonesia (Cetakan I). Yogyakarta: FPPD.

Tjondronegoro. (1978). Recent Indonesian Rural Development: Dilemma of Top-Down Approarch. Southeast Asian Affairs.

Van Jaarsveld. (2000). Affirmative Action: A Comparison between South Africa dan the United States. Managerial Law, Vol. 42 No.

Vel \& Bedner. (2015). Decentralisation and Village Governance in Indonesia : theee Return to the Nagari and the 2014 Village Law. The Journal of Legal Pluralism and Unofficial Law, Vol. 47 No, 493-507.

Wicaksono, Y. P., Surya, I., \& Iskandar, E. (2017). Peran Badan Usaha Milik Desa (BUMDes) Amanah dalam Meningkatkan Pendapatan Asli Desa Padang Jaya Kecamatan Kuaro kabupaten Paser, 5(4), 1637-1650.

Widjaja, A. . (2012). Indonesia : In Search Of Placement-support social Protection. ASEAN Economic Bullletin, Vol. 29 No.

Widjajanti, K. (2011). Model Pemberdayaan Masyarakat. Jurnal Ekonomi Pembangunan, 12. No.1.

Yasa I Kadek Suarita, Purnamawati, I. G. A., \& Sujana, E. (2017). Analisis Restrukturisasi Kredit Dalam Upaya Meningkatkan Kualitas Kredit Pada BUMDes "Gunung Sari Mas" Di Desa Dinas Bulian, Kecamatan Kubutambahan, Kabupaten Buleleng. JIMAT (Jurnal Ilmiah Mahasiswa Akuntansi) Undiksha, 8(2). 